\title{
СВІТОВИЙ ДОСВІД ЗАПРОВАДЖЕННЯ ГНУЧКИХ МЕТОДОЛОГІЙ УПРАВЛІННЯ КОНКУРЕНТОСПРОМОЖНІСТЮ ПІДПРИЕМСТВ ТА ОРГАНІЗАЦІЙ
}

\author{
Светлана Повная
МИРОВОЙ ОПЫТ ВНЕДРЕНИЯ ГИБКИХ МЕТОДОЛОГИЙ УПРАВЛЕНИЯ КОНКУРЕНТОСПОСОБНОСТЬЮ ПРЕДПРИЯТИЙ И ОРГАНИЗАЦИЙ

\author{
Svitlana Povna
WORLD EXPERIENCE IN INTRODUCTION OF FLEXIBLE MANAGEMENT METHODOLOGIES OF ENTERPRISES AND ORGANIZATIONS COMPETITIVENESS

У статті досліджено особливості методологій гнучкого управління, серед яких виділено Кайдзен та Аджайл. Ці методології призначені для роботи в змінних умовах ринку та вимог спожсивачів. Відзначено, щчо всі ці методології спрямовані на еволючійний розвиток організачій, тобто поступові удосконалення, щзо в кінцевому підсумку підтримує конкурентоспроможність організацій на високому рівні. Виділені складові Кайдзен та Аджсайл, порівняно їхні базові приниипи. Відзначено, шо Кайдзен став витоком для деяких методик Аджайл. Проведено аналіз запровадження у світі гнучкої методології Аджайл, щь показав поширення ї̈ впливу в глобальному світі. Переваги прийняття Agile, які отримують компанії, що впроваджують гнучку технологію - ие насамперед здатність управляти мінливими пріоритетами, наочність проєкту, узгодження бізнесу з IT, моральний дух команди тощо. Водночас $\epsilon$ багато проблем впровадження иієї методології, однією з основних є організаиійна культура, що не сприяє змінам та спілкуванню. Але деякі методи Аджайл, наприклад Скрам, мають досить чіткі правила запровадження, які треба вводити иілком та слідувати їм треба повністю. Проблеми запровадження Скраму здебільшого пов'язані з недостатнім слідуванням прочесу Скраму, які нівелюють його переваги. Методологія Аджайл допомагає розвиватися організачіям більще критичного розміру для подібних організацій.

Ключові слова: гнучкі методології управління; конкурентоспроможність; Кайдзен; Аджайл; Скрам; Канбан.

Табл.: 4. Бібл.: 21.

В статье исследованы особенности методологий гибкого управления, среди которых выделены Кайдзен и Аджайл. Эти методологии предназначены для работы в изменяющихся условиях рынка и требований потребителей. Отмечено, что все эти методологии направлень на эволючионное развитие организаций, то есть постепенные усовершенствования, которые в конечном счете поддерживают конкурентоспособность организаций на высоком уровне. Выделены составляюшие Кайдзен и Аджайл, проведено сравнение их базовых приниипов. Отмечено, что Кайдзен стал истоком для некоторых методик Аджайл. Проведен анализ внедрения в мире гибкой методологии Аджсайл, показавиий распространение ее влияния в глобальном мире. Преимущества принятия Agile, которые получают компании, внедряющие гибкую технологию - это прежде всего способность управлять меняющимися приоритетами, наглядность проекта, согласование бизнеса с ИТ, моральный дух команды. Вместе с тем, существует много проблем внедрения этой методологии, одной из основных является организационная культура, не способствующая изменениям и коммуникациям. Однако некоторые методы Аджайл, например Скрам, имеют достаточно четкие правила внедрения, которые надо вводить иеликом, и следовать им надо полностью. Проблемы внедрения Скрама в основном связаны с недостаточным следованием прочессу Скрама, что нивелирует его преимущества. Методология Аджайл помогает развиваться организачиям больше критического размера для подобныхх организачий.

Ключевые слова: гибкие методологии управления; конкурентоспособность; Кайдзен, Аджайл; Скрам; Канбан.

Табл.: 4. Библ.: 21 .

The article explores the features of flexible management methodologies, among which Kaizen and Agile are highlighted. These methodologies are designed to work in changing market conditions and customer requirements. It is noted that all these methodologies are focused on the evolutionary development of organizations, thus gradual improvements that ultimately maintain the competitiveness of organizations at a high level. The components of Kaizen and Agile are highlighted and their basic principles are compared. It is noted that Kaizen has become the source for some Agile techniques. An analysis of the implementation of the Agile methodology in the world was carried out, which showed the spread of its influence in the global world. The advantages of adopting Agile that companies implemented flexible technology receive are primarily the ability to manage changing priorities, the visibility of the project, aligning business with IT, and team morale. However, there are many problems with the implementation of this methodology; one of the main is the organizational culture that does not contribute to change and communication. However, some Agile methods, such as Scrum, have fairly clear implementation rules that must be introduced in their entirety, and they must be fully followed. The problems of Scrum introduction are mainly connected with insufficient adherence to the Scrum process, which eliminates its advantages. The Agile methodology helps organizations grow larger than the critical size for such organizations.

Keywords: flexible management methodologies; competitiveness; Kaizen; Agile; Scrum; Kanban.

Table: 4. References: 21.

JEL Classification: L290 
ТЕОРЕТИЧНІ ПРОБЛЕМИ РОЗВИТКУ НАЦІОНАЛЬНОЇ ЕКОНОМІКИ

Постановка проблеми. Рівень менеджменту підприємств та організацій відіграє суттєву роль у їх конкурентоспроможності. У літературі достатньо часто використовують «універсальне» трактування конкурентоспроможності як здатності регіону чи організації розробляти та виготовляти товари й послуги або вищої якості, або ж за цінами, значно нижчими порівняно з конкурентами [4, с. 117]. У сучасних умовах господарювання підприємств відбувається загострення конкурентної боротьби в усіх секторах економіки [3, с. 33].

Водночас до основних умов, в яких сьогодні функціонують суб'єкти господарювання, найчастіше належать: динамізм та хаотичність змін бізнес-середовища, підвищену турбулентність, невизначеність, нестабільність, непередбачуваність, непостійність, складність, екстремальність тощо. При цьому заслуговує на увагу думка щодо необхідності поглиблення системи методів сучасних досліджень новим турбулентним підходом, що дозволить краще пізнати закономірності розвитку соціально-економічних систем у хаотичному світі, коли стає занадто складно передбачити подальші трансформації зовнішнього середовища [13]. Для характеристики особливого стану сучасного бізнессередовища, що формується під впливом таких умов, застосовується концепція VUCAсвіту, в основу якої покладено використання англомовного акроніму з початкових літер чотирьох слів: 1) Volatility (мінливість, волатильність); 2) Uncertainty (невідомість, непередбачуваність); 3) Complexity (складність); 4) Ambiguity (неоднозначність, багатозначність) [11, с. 100].

У цих умовах незамінними є сучасні гнучкі методології розвитку організацій, що покликані підвищити конкурентоспроможність суб'єктів господарювання шляхом їх постійних вдосконалень та швидкого реагування на зміни вимог ринку та споживачів.

Аналіз останніх досліджень і публікацій. Проблемам гнучких методологій управління присвячені публікації, серед яких можна виокремити таких авторів: Масаакі Імаї [8], Р. Коула [7], Е. Скотчер [7], К. Швабер [18], Дж. Сазерленд [18], Е. Стеллман [12], Дж. Грин [12] та інших. Також відзначимо звіти, що присвячені аналізу ступеня впровадження Agile у світі [17; 19].

Виділення недосліджених частин загальної проблеми. Актуальність теми дослідження зумовлена тим, що рівень менеджменту підприємств відіграє суттєву роль в їх конкурентоспроможності; необхідність швидко адаптуватися до мінливих умов ринку та потреб споживачів робить актуальним впровадження гнучких методологій управління. Рівень менеджменту може значно підвищитися при використанні сучасних гнучких методологій, що використовуються сьогодні організаціями-лідерами. Прагнення імітувати підприємства-лідери та застосовувати їхніх досвід є достатньо важливим для підвищення конкурентоспроможності підприємств України.

Мета статті. Мета статті полягає в дослідженні світового досвіду запровадження гнучких методологій управління та аналізу можливостей їх використання для розвитку вітчизняних підприємств та організацій.

Виклад основного матеріалу. Серед гнучких методологій розвитку підприємств та організацій насамперед виділимо Кайдзен та Аджайл (Agile). Базовий принцип гнучких методологій - це еволюція: усе має постійно поліпшуватися.

Батьківщиною Кайдзен є Японія, масовий рух Кайдзен як філософії управління виник $з$ 1950-х рр. Основою Кайдзен є постійні удосконалення у функціонуванні підприємств, тому в Японії вважають, що підприємства не можуть залишатись незмінними через деякий проміжок часу (суттєві зміни зазвичай помітні в межах 4-5 років). За процес удосконалення відповідальні всі - менеджери всіх ланок та робітники. Тому в Японії широко розвинена система прийняття пропозицій від працівників, і керівники не шкодують часу на розгляд цих пропозицій. 
ТЕОРЕТИЧНІ ПРОБЛЕМИ РОЗВИТКУ НАЦІОНАЛЬНОЇ ЕКОНОМІКИ

У Кайдзен робиться наголос на таких аспектах: 1) Кайдзен починається з визнання того, що у компанії є проблеми, і кожна особа може відкрито говорити про них; 2) орієнтація на споживача, причому у виробництві споживачем вважається наступний процес обробки; 3) чітке дотримання стандартів роботи (дисципліна) з еволюційним удосконаленням стандартів; 4) якість вважається важливішою за прибуток, оскільки якість є джерелом прибутку; 5) розвиток міжфункціонального менеджменту - різні підрозділи мають координувати свої дії; 6) процесне мислення - підтримання прагнення співробітників до досконалості, відмічаючи зусилля в цьому напрямі [8].

Кайдзен породжує мислення, орієнтоване на процес, оскільки, щоб отримати більш високі результати, треба спочатку поліпшити процес. До того ж Кайдзен розрахований на удосконалення самої людини і на зусилля, що вона робить у напрямі удосконалення. Відзначається, що відсутність внутрішньої системи, що винагороджує зусилля, та оцінка кожного тільки за результатами призводить до акценту уваги лише на тих діях, які можуть дати миттєвий і високий ефект. Але поступові удосконалення Кайдзен звичайно не дають одразу видимий результат. Цю роботу можна побачити лише через значний проміжок часу.

Батьківщиною методології Agile $є$ США, і складається вона 3 таких напрямів, як Scrum (Скрам), Lean (бережливе управління), Канбан тощо. Ця методологія була розроблена для сфери розробки програмного забезпечення. Але потім з'ясувалося, що ці загальні принципи може використовувати будь-яка організація, що хоче мати гнучкість в управлінні проєктами. Порівняння основних аспектів Кайдзен та Аджайл надано в табл. 1.

Таблиця 1

Порівняння гнучких методологій розвитку підприємств

\begin{tabular}{|c|c|c|}
\hline Аспект & Кайдзен & Аджсайл \\
\hline $\begin{array}{l}\text { Сфера } \\
\text { застосування }\end{array}$ & Функціонування підприємств & Управління проєктами \\
\hline Батьківщина & Японія, з 1950-х рр. & США, $з$ 1990-х pp. \\
\hline Складові & $\begin{array}{l}\text { Контроль якості (TQC), роботизація, } \\
\text { автоматизація, система пропозицій, } \\
\text { концепція «just in time», Канбан тощо }\end{array}$ & Скрам, Lean (бережливе управління), Канбан \\
\hline $\begin{array}{l}\text { Базові } \\
\text { принципи }\end{array}$ & $\begin{array}{c}\text { Орієнтація на вимоги споживача. } \\
\text { Якість важливіша за прибуток. } \\
\text { Увага до проблем з метою їх вирішення. } \\
\text { Удосконалення людей. } \\
\text { Чітке дотримання стандартів та їх пос- } \\
\text { тупове удосконалення. } \\
\text { Управління попереднім процесом. } \\
\text { Міжфункціональний менеджмент, коор- } \\
\text { динація дій різних підрозділів } \\
\text { Процесне мислення як підтримання пра- } \\
\text { гнення співробітників до досконалості, } \\
\text { відмічаючи зусилля в цьому напрямі }\end{array}$ & $\begin{array}{c}\text { Найвищим пріоритетом є задоволення потреб } \\
\text { замовника, завдяки регулярній і ранній } \\
\text { поставці цінного продукту. } \\
\text { Зміна вимог вітається, навіть на пізніх стадіях } \\
\text { розробки. } \\
\text { Розробники й бізнес-представники повинні } \\
\text { щодня працювати разом. } \\
\text { Спілкування є найкращим способом обміну } \\
\text { інформацією. } \\
\text { Постійна увага до технічної досконалості } \\
\text { та якості. } \\
\text { Систематичний аналіз способів поліпшення } \\
\text { ефективності й відповідне коригування роботи }\end{array}$ \\
\hline $\begin{array}{l}\text { Умови } \\
\text { впровадження }\end{array}$ & $\begin{array}{l}\text { Бачення недосконалості; повільний } \\
\text { розвиток економіки }\end{array}$ & $\begin{array}{l}\text { Невизначеність та швидкі зміни зовнішнього } \\
\text { середовища }\end{array}$ \\
\hline
\end{tabular}

Джерело: систематизовано автором на основі $[8 ; 15]$.

Основою Аджайл є гнучкість, тобто постійні удосконалення та підналаштування процесу роботи шляхом консультацій із замовниками. Звичайні стандарти управління проєктами передбачають проходження чітко описаних етапів та необхідність на початку проєкту його повністю спланувати. Відхилення від плану сприймаються як невдале управління проєктами. Але підвищення невизначеності навколишнього середовища робить важким планування всього проєкту від початку до закінчення. У Маніфесті гнуч- 
ТЕОРЕТИЧНІ ПРОБЛЕМИ РОЗВИТКУ НАЦІОНАЛЬНОЇ ЕКОНОМІКИ

кої розробки програмного забезпечення (продукту) відзначено [14]: «1) люди і взаємодія важливіше процесів та інструментів; 2) працюючий продукт важливіше вичерпної документації; 3) співпраця із замовником важливіша за узгодження умов контракту; 4) готовність до змін важливіша за проходження попереднім планом. Тобто, не заперечуючи важливості того, що справа, ми все-таки більше цінуємо те, що зліва».

Lean (бережливе управління) вважається одним із попередників сучасного Agileруху. До принципів бережливого управління належать: 1) оптимізуйте цілісне бачення; 2) виключіть втрати; 3) забезпечте якість; 4) постійно вчитеся; 5) гранично швидко здійснюйте поставку замовнику; 6) залучайте команду; 7) постійно удосконалюйтеся. Зауважимо, що ці принципи мають видимі витоки з Кайдзен.

Основи Скраму були розроблені К. Швабером та Дж. Сазерлендом [18]. Базовими принципами скраму є: повага, мужність, зобов'язання, фокус на результаті, відкритість. Скрам грунтується на емпіризмі, а саме тезі, що знання приходять із досвідом, а прийняття рішень має відбуватись на підставі того, що вже відомо. Тому робота відбувається часовими відрізками тривалістю зазвичай 2 тижні або місяць (спринтами), протягом яких створюються та узгоджуються із замовником придатні до використання удосконалення продукту. Робота спринтом зручна тим, що вона дозволяє швидко виявити недосконалості в роботі та в наступному спринті поліпшити ситуацію [18; 10].

Скрам передбачає чотири типи нарад для перевірки та адаптації [18]:

1) Планування Спринту - спершу з'ясовується список кінцевих продуктів або робіт, в яких зацікавлений замовник, серед цього списку знаходять найцінніші для замовника продукти. Далі їх розбивають на більш дрібні завдання, при цьому оцінюється цінність і складність робіт; прийнято, що спочатку роблять найлегші зі списку цінних завдань;

2) Щоденний Скрам - проводиться на етапі реалізації Спринту, що передбачає проведення щоденних зборів, стоячи максимум 15 хвилин, на яких кожен член команди розповідає: 1) що вдалося зробити вчора; 2) що зробить сьогодні; 3) які є перешкоди;

3) Огляд Спринту - відбувається в кінці кожного Спринту, де готові результати представляються замовнику, який може вносити зауваження та побажання. Отже, команда отримує швидкий відгук на результати роботи, а також задоволеного замовника, який за Спринт отримав цінну готову роботу; при цьому якщо команда не повністю зрозуміла замовника (або замовник спочатку нечітко сформулював вимоги), то це з'ясовується на огляді Спринту й обсяг переробок невеликий. Відзначимо, що згідно 3 новим визначенням «успішного проєкту», яке набрало чинності з 2011 р., поняття «задоволеного замовника» вважається основним поряд із досягненням цілей проєкту, а також відповідності термінам і бюджету $[10 ; 16]$;

4) Ретроспектива Спринту - команда збирається окремо після огляду Спринту, в ході наради обговорюється, які уроки можна витягти з результатів Спринту, а саме: 1) що робилося успішно; 2) що можна було зробити краще; 3 ) що можна вдосконалити в майбутньому.

Зауважимо, що Канбан - це спільна техніка для Кайдзен та Аджайл, що передбачає насамперед обмеження завдань, які виконуються в цей момент для підвищення продуктивності та зменшення незавершеного виробництва. Різниця у візуальній методиці використання для Кайдзен та Agile зумовлена різним типом процесів, на який вони розраховані. Так, канбан у Кайдзен - це бирка, призначена для «витягування» 3 попереднього процесу необхідної кількості напівфабрикатів та використовується в системі «just in time» [8]. Як приклад використання в Україні цієї методики можна відзначити випадок, коли мережа супермаркетів Сільпо на деякий період карантинних обмежень запровадила жетони, які видавались кожному відвідувачу на вході, а на виході їх треба було здавати. Після закінчення жетонів на вході заборонялося заходити наступним відвідувачам доти, поки хтось із відвідувачів не вийде і не здасть свій жетон, таким чином були використані канбан-жетони для обмеження ємності системи. 
ТЕОРЕТИЧНІ ПРОБЛЕМИ РОЗВИТКУ НАЦІОНАЛЬНОЇ ЕКОНОМІКИ

Візуальна методика Канбан в Agile - це використання дошки для управління процесом виконання робіт, що передбачає наклеювання маленьких листків з назвами робіт на дошку, яка у свою чергу поділена на сегменти «ідеї», «зробити», «у процесі», «зроблене»; робота вважається тим більш пріоритетною, чим ближче вона до завершення. Призначення цієї дошки - також слідкувати за обмеженням кількості задач, які взяли на себе працівники. Канбан - це набір інструментів і метрик, його успіх визначається збором даних про робочий процес та їх регулярним аналізом. Він не дає жорстких установок про те, які саме інструменти і в якій комбінації застосовувати, оскільки розрахований на довгу еволюційну зміну існуючої системи [6].

Починаючи з 2007 р. у світі проводяться регулярні дослідження ступеня запровадження методології Agile. У дослідженні за 2018 р. було зауважено збільшення глобальної різноманітності, тобто Свропа, Азія, Південна Америка та Африка продемонстрували збільшення у відсотках до загальної кількості респондентів. У 2018 р. 53 \% респондентів були з-поза меж Північної Америки в порівнянні із $45 \%$ в 2017 p. (табл. 2). В Україні методологія Agile також використовується, але переважно в організаціях, зайнятих розробкою програмного забезпечення. Зазначимо, що в Україні IT-сектор зростає, і щорічно збільшує кількість робочих місць на 2,5-4,0 \% [21].

Таблиця 2

Локайія організаиій-респондентів (відсоток респондентів)

\begin{tabular}{|l|c|c|c|}
\hline \multicolumn{1}{|c|}{ Країна } & $\mathbf{2 0 1 7}$ & $\mathbf{2 0 1 8}$ & Відхилення 2018-2017 рр., п.П. \\
\hline Північна Америка & 55 & 47 & -8 \\
\hline Свропа & 27 & 30 & 3 \\
\hline Азія & 7 & 10 & 1 \\
\hline Північна Америка & 7 & 8 & 0 \\
\hline Австралія, Нова Зеландія & 3 & 3 & 1 \\
\hline Африка & 1 & 2 & \\
\hline
\end{tabular}

Джерело: проаналізовано автором за [19; 20].

Отже, Agile набирає поширення у світі. Переваги прийняття Agile, які отримують компанії, що впроваджують гнучку технологію - це насамперед здатність управляти мінливими пріоритетами, наочність проєкту, узгодження бізнесу з IT, моральний дух команди тощо (табл. 3). Порівнюючи динаміку результатів за 2017-2018 р., треба відзначити збільшення морального духу команди $(64 \%$ у 2018 р. в порівнянні з $61 \%$ в 2017 р.), а також збільшення передбачуваності проєктів (відповідно 52 \% в порівнянні 3 49 \%) і зниження проєктного ризику (відповідно 50 \% в порівнянні з 47 \%). Agile стає тим більш важливим, що Україна має значні проблеми у сфері реалізації державних інвестиційних проєктів [9].

Таблиця 3

Переваги, які отримують компанії при впровадженні Agile

(\% респондентів, респонденти мали можливість обирати декілька пунктів)

\begin{tabular}{|l|c|c|c|}
\hline \multicolumn{1}{|c|}{ Переваги } & $\mathbf{2 0 1 7}$ & $\mathbf{2 0 1 8}$ & Відхилення 2018-2017 рр. п.п. \\
\hline Здатність управляти мінливими пріоритетами & 71 & 69 & -2 \\
\hline Наочність проєкту & 66 & 65 & -1 \\
\hline Узгодження бізнесу / ІТ & 65 & 64 & -1 \\
\hline Моральний дух команди & 61 & 64 & 3 \\
\hline Швидкість доставки / час до ринку & 62 & 63 & 1 \\
\hline Підвищення продуктивності команди & 61 & 61 & 0 \\
\hline Передбачуваність проєкту & 49 & 52 & 3 \\
\hline Зниження ризику проєкту & 47 & 50 & 3 \\
\hline Якість програмного забезпечення & 47 & 47 & 0 \\
\hline Інженерна дисципліна & 43 & 42 & -1 \\
\hline Управління розподіленими командами & 40 & 39 & -1 \\
\hline Зниження вартості проєкту & 22 & 28 & 6 \\
\hline
\end{tabular}

Джерело: проаналізовано автором за $[19 ; 20]$. 
ТЕОРЕТИЧНІ ПРОБЛЕМИ РОЗВИТКУ НАЦІОНАЛЬНОЇ ЕКОНОМІКИ

Опитування показують, що культурні проблеми організації залишаються основними перешкодами для прийняття Agile (табл. 4).

Таблиця 4

Виклики прийняття Agile

(\% респондентів, респонденти мали можливість обирати декілька пунктів)

\begin{tabular}{|l|c|c|c|}
\hline \multicolumn{1}{|c|}{ Переваги } & $\mathbf{2 0 1 7}$ & $\mathbf{2 0 1 8}$ & Відхилення 2018-2017 рp. п.І. \\
\hline $\begin{array}{l}\text { Організаційна культура розходиться з гнучкими } \\
\text { цінностями }\end{array}$ & 53 & 52 & -1 \\
\hline Загальна організація опирається змінам & 46 & 48 & -2 \\
\hline Неадекватна управлінська підтримка і спонсорство & 42 & 44 & 2 \\
\hline $\begin{array}{l}\text { Відсутність навичок / досвіду роботи з гнучкими } \\
\text { методами }\end{array}$ & 41 & 40 & -1 \\
\hline Несумісні процеси і практики в командах & 34 & 35 & 1 \\
\hline Недостатня підготовка та освіта & 35 & 36 & 1 \\
\hline $\begin{array}{l}\text { Недостатність доступності бізнесу / клієнта / влас- } \\
\text { ника продукту }\end{array}$ & 31 & 32 & 1 \\
\hline Поширеність традиційних методів розвитку & 30 & 28 & -2 \\
\hline $\begin{array}{l}\text { Фрагментовані інструменти і дані / вимірювання, } \\
\text { пов’язані з проєктом }\end{array}$ & 24 & 26 & 2 \\
\hline Мінімальна співпраця і обмін знаннями & 21 & 24 & 3 \\
\hline Відповідність нормативним вимогам & 14 & 16 & 2 \\
\hline
\end{tabular}

Джерело: проаналізовано автором за [19; 20].

Загальний опір змінам, неадекватна управлінська підтримка, а також організаційна культура, що суперечить гнучким цінностям, входять до трійки основних проблем, що заважають прийняттю гнучкої методології Agile. Незважаючи на те, що підтримка Agile продовжує збільшуватись, більшість респондентів (78 \%) заявляють, що не всі команди їх компаній працюють за гнучкими методами [20]. Але досвід показує, якщо новий підхід охопив 30 \% компанії, то далі він починає поширюватися сам, і йому більше не потрібен захист вищого керівництва. Впровадження Scrum взагалі вимагає великих змін, як у структурі організації, так і в контрактуванні з підрядниками (потрібен контракт time \& material), і в бюджетуванні (поетапне бюджетування) [5].

Водночас сьогодні вже існує і критика Agile, яка каже про те, що коли ці методи проявляються на місцях, вони інколи заважають, а не допомагають гарній роботі. Навіть прихильники Agile кажуть, що ця методологія підходить не всім [17]. Називають навіть 85 проблем, що можуть виникнути при впровадженні гнучких методів, які зазвичай належать до впровадження Скраму [1]. Ці проблеми здебільшого пов'язані з недостатнім розумінням особливостей застосування інструментів [5].

Agile не потрібний там, де запорука успіху в проходженні чітко заданому алгоритму дій. Agile буде шкідливий там, де вартість «переробки» або «доопрацювання» продукту колосальна або навіть може бути пов'язана з людськими жертвами. Крім того, впровадження Скраму не є дешевою процедурою: адже потрібно сформувати повноцінну команду, яка буде зайнята тільки розробкою визначеного продукту; також треба брати до уваги, що мінімум 8 годин за спринт буде витрачатися на комунікацію, так як Scrum передбачає серію обов'язкових зустрічей тривалістю 1-2 години. Однак підсумковий виграш у швидкості і якості, який забезпечує Scrum, дуже великий [5].

Уже доказано на практиці, що використання гнучких методологій допомагає організаціям розвиватися більше того розміру, який зазвичай не можуть перевершити організації із традиційними методами управління [2]. При цьому базовою вимогою є чітке дотримання правил Аджайл. 
ТЕОРЕТИЧНІ ПРОБЛЕМИ РОЗВИТКУ НАЦІОНАЛЬНОЇ ЕКОНОМІКИ

Висновки і пропозиції. Отже, вивчення світового досвіду використання передових методів управління $\epsilon$ корисним для запровадження у вітчизняних підприємствах, оскільки ці методології підтвердили свою ефективність. До гнучких методологій ми віднесли Кайдзен та Аджайл, кожна $з$ яких має свої принципи та окремі складові, але спільним ключовим їх аспектом $\epsilon$ прагнення до постійних удосконалень та постійної комунікації, в тому числі із споживачами. Використання методології Аджайл сьогодні поширюється у світовому масштабі, не $\epsilon$ винятком і Україна. Перевагами прийняття Аджайл є здатність управляти мінливими пріоритетами, наочність проєкту, моральний дух команди тощо. Водночас розходження організаційної культури з гнучкими цінностями є головною перешкодою на шляху запровадження Аджайл.

\section{Список використаних джерел}

1. 85 заблуждений и препятствий внедрения гибкой разработки. URL: https://m.habr.com/ru/ company/scrumguides/blog/171895.

2. Аджайл для всех: как заставить бухгалтера быть гибким. URL: https://m.habr.com/ru/ company/knopka/blog/234703.

3. Бабаченко Л., Ковшун Х., Портна Ю. Особливості управління конкурентоспроможністю підприємства. Проблеми і перспективи економіки та управління. 2019. № 3. С. 33-40.

4. Бутко М. П. Архітектоніка конкурентоспроможності регіонів України в контексті євроінтеграції : монографія. Київ : АМУ, 2016. 452 с.

5. Всё дело в Agile - 1: популярные мифы о гибкой разработке. URL: https://m.habr.com/ru/ company/mailru/blog/430766.

6. Все дело в Agile - 2: особенности внедрения гибкой разработки. URL: https://habr.com/ru/ company/mailru/blog/431898/?_ga=2.201160686.1552669034.1586757346-577063148.1559815610.

7. Коул Р., Скотчер Э. Блистательный Agile. Гибкое управление проектами с помощью Agile, Scrum и Kanban. Санкт-Петербург : Питер, 2019. 304 с.

8. Масааки Имаи. Кайдзен: ключ к успеху японских компаний / пер. с англ. Москва : Альпина Бизнес Букс, 2004. 274 с.

9. Повна С. В. Методологія проектного менеджменту в управлінні державними інвестиційними проектами. Публічне адміністрування: наукові дослідження та розвиток. 2017. № 1(3). C. 101-107.

10. Повная С. Скрам как современный метод организации работы в условиях сложности и неопределенности внешней среды. Aktualne problemy nowoczesnych nauk -2019”, 07-15 czerwca 2019 roku po sekcjach: Politologia. Historia. Prawo : Materialy XV Miedzynarodowej naukowipraktycznej konferencji. Przemysl: Nauka I studia, 2019, Vol.6 S. 3-5. URL: http://www.rusnauka.org/cgi-bin/search/step7_info.cgi?id=252613\&idw=Ue2DmWQp0jw1zoBwQx.

11. Ремньова Л. Основні виклики та детермінанти нової моделі управління персоналом у VUCA-світі. Проблеми і перспективи економіки та управління. 2019. № 3. С. 99-105.

12. Стеллман Э., Грин Дж. Постигая Agile: ценности, принципы, методологии / пер. с англ С. Пасерба. Москва : Манн, Иванов и Фербер, 2017. 448 с.

13. Шкарлет С. М., Дубина М. В. Застосування турбулентного підходу до пізнання економічних систем. Науковий вісник Полісся. 2017. № 1(9), ч. 1. С. 8-15. URL: https://nvp.stu.cn.ua/ru/ item/623-application-of-turbulent-approach-to-the-knowledge-of-the-economic-systems/623application-of-turbulent-approach-to-the-knowledge-of-the-economic-systems.html.

14. Agile Manifesto. Copyright 2001: Kent Beck, Mike Beedle, Arie van Bennekum, Alistair Cockburn, Ward Cunningham, Martin Fowler, James Grenning, Jim Highsmith, Andrew Hunt, Ron Jeffries, Jon Kern, Brian Marick, Robert C. Martin, Steve Mellor, Ken Schwaber, Jeff Sutherland, Dave Thomas. URL: https://agilemanifesto.org.

15. Beck et al., "The Principles Behind the Manifesto". URL: http://www.agilemanifesto.org/ principles.html.

16. M. Daud Alam, Uwe F. Guhl. Project-Management in Practice. A Guideline and Toolbox for Successful Projects. Springer - Verlag GmbH Germany, 2016. 183 p. 
ТЕОРЕТИЧНІ ПРОБЛЕМИ РОЗВИТКУ НАЦІОНАЛЬНОЇ ЕКОНОМІКИ

17. Mo Hagar. Maybe Agile Is the Problem. URL: https:/www.infoq.com/articles/agile-agileblah-blah.

18. Schwaber, K., Sutherland, J. (2017). The official Scrum Guide. URL: https://www.scrumguides.org.

19. The $12^{\text {th }}$ annual state of Agile report / Collabnet, Versionone. URL: stateofagile.com.

20. The $13^{\text {th }}$ annual state of Agile report / Collabnet, Versionone. URL: stateofagile.com.

21. Vdovenko N., Deriy J., Seliverstova L., Kurmaiev P. Formation of the information economy: Organizational and financial aspects. International Journal of Supply Chain Management. 2019. Vol. 8, No 4. P. 956-961.

\section{References}

1. 85 zabluzhdeniy i prepyatstviy vnedreniya gibkoy razrabotki [85 fallacies and hurdles of implementing agile development]. Retrieved from https://m.habr.com $/ \mathrm{ru} / \mathrm{company} / \mathrm{scrumguides} /$ blog/171895.

2. Adzhayl dlya vseh: kak zastavit buhgaltera byit gibkim [Agile for all: how to get an accountant to be flexible]. Retrieved from https://m.habr.com/ru/company/knopka/blog/234703.

3. Babachenko, L., Kovshun, Kh., Portna, Yu. (2019). Osoblyvosti upravlinnia konkurentospromozhnistiu pidpryiemstva [Features of enterprise competitiveness management]. Problemy i perspektyvy ekonomiky ta upravlinnia - Problems and prospects of economy and management, 3, 33-40 [in Ukrainian].

4. Butko, M. P. (2016). Arkhitektonika konkurentospromozhnosti rehioniv Ukrainy v konteksti yevrointehratsii: monohrafiia [Architecture of competitiveness of Ukrainian regions in the context of European integration]. Kyiv: AMU [in Ukrainian].

5. Vse delo v Agile - 1: populyarnyie mifyi o gibkoy razrabotke [It's All About Agile 1: Popular Agenda Myths]. Retrieved from https://m.habr.com/ru/company/mailru/blog/430766/

6. Vse delo v Agile - 2: osobennosti vnedreniya gibkoy razrabotki [It's All About Agile - 2: Agile Implementation Features]. Retrieved from https://habr.com/ru/company/mailru/blog/ 431898/? ga $=2.201160686 .1552669034 .1586757346-577063148.1559815610$

7. Koul, R., Skotcher, E. (2019). Blistatelnyiy Agile. Gibkoe upravlenie proektami s pomoschyu Agile, Scrum i Kanban [Brilliant Agile. Flexible project management with Agile, Scrum and Kanban]. Sankt-Peterburg: Piter [in Russian].

8. Masaaki Imai (2004). Kaydzen: klyuch $k$ uspehu yaponskih kompaniy [Kaizen: the key to the success of Japanese companies]. Moscow: Alpina Biznes Buks [in Russian].

9. Povna, S. V. (2017). Metodolohiia proektnoho menedzhmentu v upravlinni derzhavnymy investytsiinymy proektamy [Methodology of project management in the management of public investment projects]. Publichne administruvannia: naukovi doslidzhennia ta rozvytok - Public administration: research and development, 1(3), 101-107 [in Ukrainian].

10. Povnaya, S. (2019). Skram kak sovremennyiy metod organizatsii rabotyi v usloviyah slozhnosti i neopredelennosti vneshney sredyi [Scrum as a modern method of organizing work in conditions of complexity and uncertainty of the external environment]. Materialy XV Miedzynarodowej naukowipraktycznej konferencji, "Aktualne problemy nowoczesnych nauk -2019”, 07-15 czerwca po sekcjach: Politologia. Historia. Prawo (Vol. 6, pp. 3-5). Przemysl: Nauka I studia [in Russian].

11. Remnova, L. (2019). Osnovni vyklyky ta determinanty novoi modeli upravlinnia personalom u VUCA-sviti. Problemy i perspektyvy ekonomiky ta upravlinnia [Key Challenges and Determinants of a New Personnel Management Model in the VUCA World]. Problemy i perspektyvy ekonomiky ta upravlinnia - Problems and prospects of economy and management, 3, 99-105 [in Ukrainian].

12. Stellman, E., Grin, Dzh. (2017). Postigaya Agile: tsennosti, printsipyi, metodologii [Comprehending Agile: Values, Principles, Methodologies]. Moscow: Mann, Ivanov i Ferber [in Russian].

13. Shkarlet, S. M., Dubyna, M. V. (2017). Zastosuvannia turbulentnoho pidkhodu do piznannia ekonomichnykh system [Application of turbulent approach to the knowledge of the economic systems]. Naukovyy visnyk Polissia - Scientific Bulletin Polissia, 1 (1(9)), 8-15. Retrieved from https://nvp.stu.cn.ua/ru/-/item/623-application-of-turbulent-approach-to-the-knowledge-of-theeconomic-systems/623-application-of-turbulent-approach-to-the-knowledge-of-the-economicsystems.html. 
ТЕОРЕТИЧНІ ПРОБЛЕМИ РОЗВИТКУ НАЦІОНАЛЬНОЇ ЕКОНОМІКИ

14. Agile Manifesto. Copyright 2001: Kent Beck, Mike Beedle, Arie van Bennekum, Alistair Cockburn, Ward Cunningham, Martin Fowler, James Grenning, Jim Highsmith, Andrew Hunt, Ron Jeffries, Jon Kern, Brian Marick, Robert C. Martin, Steve Mellor, Ken Schwaber, Jeff Sutherland, Dave Thomas. Retrieved from https://agilemanifesto.org/

15. Beck et al. The Principles Behind the Manifesto. Retrieved from http://www.agilemanifesto.org/ principles.html.

16. M. Daud Alam, Uwe F. Guhl. Project-Management in Practice. A Guideline and Toolbox for Successful Projects. Springer - Verlag GmbH Germany, 2016. 183 p.

17. Mo Hagar. Maybe Agile Is the Problem. Retrieved from https://www.infoq.com/articles/agileagile-blah-blah.

18. Schwaber, K., Sutherland, J. (2017). The official Scrum Guide. Retrieved from https://www.scrumguides.org.

19. The $12^{\text {th }}$ annual state of Agile report / Collabnet, Versionone. Retrieved from stateofagile.com.

20. The $13^{\text {th }}$ annual state of Agile report / Collabnet, Versionone. Retrieved from stateofagile.com.

21. Vdovenko N., Deriy J., Seliverstova L., Kurmaiev P. (2019). Formation of the information economy: Organizational and financial aspects. International Journal of Supply Chain Management. $8(4), 956-961$.

Повна Світлана Вікторівна - кандидат економічних наук, доцент, доцент кафедри менеджменту та держа-

вної служби, Чернігівський національний технологічний університет (вул. Шевченка, 95, м. Чернігів, 14035,

Україна).

Повная Светлана Викторовна - кандидат экономических наук, доцент, доцент кафедры менеджмента и

государственной службы, Черниговский национальный технологический университет (ул. Шевченко, 95,

г. Чернигов, 14035, Украина)

Povna Svitlana - PhD in Economics, Associate Professor, Associate Professor of Department of Management and

Public Service, Chernihiv National University of Technology (95 Shevchenka St., 14035 Chernihiv, Ukraine).

E-mail: svitlanapovna@gmail.com

ORCID: https://orcid.org/0000-0002-0654-9868

ResearcherID: G-9355-2016 